of their readers to further study and investigation of the principles and laws that govern their professional methods. I confess to not finding a dull page in the book. I have but one harsh word to say of it and its authors. They should be sentenced to make indexes for the rest of their natural lives.

Marling School, Stroud.

W. J. Greenstreet.

Atonement and Personality. By R. C. Moberly, D. D. London: John Murray, I901. Pp. xxviii. 418.

Dr. Moberly endeavors in this work to re-state the doctrine of the Atonement in such a way as to bring it more into harmony with the ethical spirit which is permeating recent theology. For this purpose he investigates in a very admirable way the ethical conceptions or elements involved in the notion of atonement, conceptions such as punishment, penitence, forgiveness, vicarious suffering. His re-statement of the doctrine is based, however, on an unquestioning acceptance of the traditional doctrines of the Trinity and the Incarnation, and makes the ethical process, in which atonement essentially consists, depend for its possibility upon the truth of the ontological mysteries set forth in these doctrines. In spite of Dr. Moberly's very evident earnestness, candor, and patient reflection, this unhappy combination of ethics and metaphysics in theology seems only to illustrate once more the result of putting new wine into old wine-skins. The strain put upon the traditional doctrines is more than they can bear.

It would be impossible in a brief space to do justice to Dr. Moberly's argument as a whole. For it is only fair to say that, within the limits of his presuppositions, Dr. Moberly has gone to work in no narrow spirit, but has striven to attain a large and coherent conception of the doctrine of the Atonement both in itself and in its various relations. But while there is much that calls for detailed examination, it must suffice here to illustrate what has just been said to be the radical defect of the work, by stating briefly the central part of the argument. In analyzing the conception of penitence Dr. Moberly argues that a true penitence for sin is possible only in so far as the sinner rises above his sin. Perfect penitence, then, would seem to be possible only for one who is also sinless (an inference, by the way, which is open to obvious criticism, and which Dr. Moberly can hardly be said to 
defend with success). For sinners, on the other hand, only an approximation to it is possible, unless they can somehow participate in a perfection not their own; since for man as man sinless perfection is not possible. It is only in Christ, the incarnate Son of God, that sinless perfection, and therefore a perfect penitence, is possible originally and directly. Now atonement for sin is realized in and through perfect penitence for sin. Thus the possibility and reality of a full and perfect atonement is grounded on the fact of Christ's Incarnation. More particularly, it is grounded on the dual nature of Christ, for it is through his humanity that he can take upon himself the burden of human sin, and through his divinity that he is capable of a sinless and perfect penitence.

Summary as this statement of the main argument is, it may serve to indicate the bearing of the following criticism. The traditional doctrine of Christ's nature makes it impossible for Dr. Moberly to entertain the thought that Christ was in any real sense capable of sin. On the other hand, the very existence of that perfect penitence, upon which the whole argument turns, depends upon this, that Christ really entered into the meaning of human temptation, was in fact himself really tempted. Hence the argument is involved in a hopeless dilemma between real temptation to sin, on the one hand, and essential inability to sin, on the other. Dr. Moberly's own language sufficiently shows the extremity to which the argument is reduced. For he tries every turn of phrase to describe "this strange, dim, vision or idea [in Christ's mind] of a possibility" [of sin], which was "not really possible," yet whose rejection required "a stupendous act or energy of victorious moral goodness" (p. Io6). There could hardly be a more convincing evidence of the unhappy influence exercised upon theology by the metaphysics of the creeds than is afforded by a single passage such as this, with its urgent appeal for our reverence and awe on behalf of a manifest unreality.

Although in the main scheme of his argument Dr. Moberly is fatally hampered by his unquestioning acceptance of the dogmas of ecclesiastical metaphysics, his work in almost every other respect calls for high praise. The scheme of the argument within its limits is carefully and systematically developed, the exposition is clear, the criticism of opposing or defective views is scrupulously fair and always ready to recognize the measure of truth they may possess. As already said, the analysis of the ethical elements in the religious doctrine is an admirable feature of the work. 
Against these merits, however, it is necessary to put one rather conspicuous defect, viz., the total absence of reference to, and presumably of acquaintance with, modern theology outside this country. The defect, no doubt, is only too common in Anglican theology, but it is not easily excused in a work of this order. The reader receives not one hint, for instance, that the greatest work in dogmatics since Schleiermacher has this very doctrine of the Atonement for its theme. Our author's apparent lack of acquaintance with the work of Ritschl and his school is the more to be regretted, because their work exhibits a far more thorough and consistent development of what is best in Dr. Moberly's book; that is to say, their work shows what an ethical theology can be when it is freed from its bondage to an alien metaphysics.

\section{EDINBURGH UNIVERSITY.}

HENRY BARKER.

A History of Politics. By Edward Jenks, M. A., Reader in Law to the University of Oxford, etc. London: J. M. Dent, I900. Pp. vi., I64.

This is one of the Temple Primers published at Aldine House. It is a history of political action and not of political speculation. Mr. Jenks has done similar work before in his "Law and Politics in the Middle Ages." But this Primer is more popular in form, and the subject is not elaborated in detail. Beginning with an introductory chapter on Types of Society, the author proceeds to trace the origin and development of the institutions of government from the savage state through the patriarchal stage to the modern form. The matter of the book is prevented in an attractive way and is well arranged. Mr. Jenks displays a wide knowledge; though at times he is inclined to make too sweeping assertions. For example he asserts that "Morality is the result, not the cause of social amelioration" (p. 27). It would be truer to say that they are mutually cause and effect of each other. Morality tends to social amelioration, and the latter prepares the way for a higher morality. The Primer is however an excellent one, and there is appended to it a useful list of authorities. It ought to be read along with Sir Frederick Pollock's "Introduction to the History of the Science of Politics."

EDINBURGH.

W. F. Trotter. 